\title{
CONCENTRATION PROFILES OF PERMEANT IN MEMBRANES UNDER PERVAPORATION \\ - A PROPOSAL OF A NEW METHOD TO DETERMINE THE PROFILES -
}

\author{
By Takashi Iwatsubo, Tadae Yamanaka, Seisyu Yamamoto, \\ Kensaku Mizoguchi and Yoshio Suda \\ (Research Institute for Polymers and Textiles, \\ 1-1-4, Higashi, Tsukuba, Ibaraki 305, Japan)
}

\begin{abstract}
An experimental method was proposed to determine the single concentration profile of permeant in a membrane under pervaporation. In this method, two individual experimental data were required. One was the relationship between the downstream pressure and the steady-state flux, and the other was the adsorption isotherm of the permeant to the membrane. According to this method, it was possible to evaluate the precise concentration profile and to be applied to the system that the permeant is easy to vaporize. By applying this method to the pervaporation of water or ethanol, the concentration profiles in the membrane were determined. They showed good agreement in shape with previous results obtained by conventional methods. Assumptions required for this method were examined experimentally, and these were valid for the permeant-membrane systems treated in this study.
\end{abstract}

\section{Introduction}

For the purpose of understanding the mechanism of permeation under pervaporation, it is important to determine precise concentration profiles of permeant in a membrane ${ }^{1,2)}$. In this work, a method was proposed to determine the profiles, and as a first step, applied to single permeant.

In order to obtain the profile, two experimental data were combined. One was the relationship between the downstream pressure and the steadystate flux, and the other was the adsorption isotherm of the permeant to the membrane.

The method is expected to give more precise profiles than those obtained by other conventional methods such as the membrane stacking method $^{3-6)}$.

\section{Theory}

Fig. 1 (a) shows two steady-state pervaporation

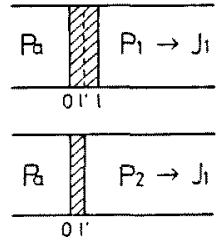

(a)

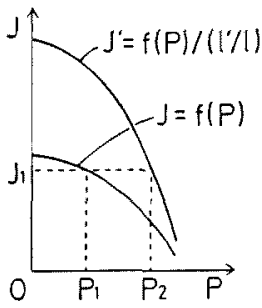

(b)
Fig. 1 Supplementary figure and diagram for explanation of the theory

conditions for the membranes with different thicknesses. For the membrare with thickness $l$ (membrane $l$ ), let the upstream pressure and the downstream pressure be $P_{\mathrm{a}}$ and $P_{1}$ respectively, and the flux be $J_{1}$. For the membrane with smaller thickness $l^{\prime}$ (membrane $l^{\prime}$ ), the equal flux $J_{1}$ can be attained by controlling the downstream pressure.

If the following assumption is valid, this controlled pressure $P_{2}$ can be regarded as the vapor 
pressure at a point $l$ in the membrane $l$.

(Assumption A): The chemical potentials of permeant at just inside and outside of membrane surface are equal. This means that an equilibrium condition is satisfied at the interfaces.

By using a lot of membranes with different thickness, a vapor pressure profile will be obtained.

In practise, however, the profile can be obtained by permeation experiments using just one membrane with a given thickness if the following assumption is accepted.

(Assumption B): The steady-state flux $J$ is inversely proportional to the membrane thickness.

The practical procedure is as follows. At first, for the membrane $l$, the relationship between the steady-state flux $J$ and the downstream pressure $P$, $J=f(P)$, can be measured by controlling the downstream pressure. Then the relationship between the steady-state flux $J^{\prime}$ and the downstream pressure $P$ for the membrane $l^{\prime}$ can be calculated from the above experimental data as follows;

$$
I^{\prime}=f(P) /\left(l^{\prime} / l\right)
$$

Now we consider the downstream pressure $P_{1}$ and the steady-state flux $J_{1}$ for the membrane $l$. Using the curve of $J^{\prime}$ calculated for a value of thickness $l^{\prime}$, the downstream pressure $P_{2}$ which yields the same value as $J_{1}$ can be obtained as shown in Fig. 1 (b). This pressure can be considered to be the vapor pressure of permeant at the point $l^{\prime}$ in the membrane $l$.

Some other assumptions are used in this work without checking their validity. For example:

(i) The membrane size does not change by the permeant adsorption. This condition will be satisfied for the membrane with low swelling ratio.

(ii) The membrane can be kept at an uniform temperature.

Assumptions $A$ and $B$ were examined experimentally in the section $4-4$ and were confirmed to be valid for the permeant-membrane systems treated in this work.

As can be understood easily from the consideration mentioned above, this method will be more useful than the membrane stacking method especially for the volatile or high diffusive per- meants.

\section{Experimental}

In this work, homogeneous cellulose acetate and silicone rubber membranes were used. The cellulose acetate membrane was casted on the glass plate at room temperature from an acetone solution of $20 \mathrm{wt} \%$ cellulose acetate (Daicell Chemical, acethyl content is $54.4 \pm 0.4 \%$ ). The thickness of the membrane was $25 \mu \mathrm{m}$. The silicone rubber membrane was $115 \mu \mathrm{m}$ thickness (Shin-Etsu Chemical). The effective surface area of each membrane was $15.6 \mathrm{~cm}^{2}$. For those membranes, pervaporation of ethanol or water was examined independently.

A schematic diagram of pervaporation apparatus used in this experiment is shown in Fig. 2. A membrane set on a metal mesh was fixed in a cylindrical holder. After steady state conditions were reached, the permeation flux was determined from the weight of permeant condensed in the cold trap for an hour. The downstream pressure was controlled by a fine valve which was operated with monitoring a $\mathrm{Hg}$ manometer. The upstream pressure was maintained at atmospheric pressure and the permeation cell was dipped in a water bath kept at $40^{\circ} \mathrm{C}$.

Measurement of adsorption isotherms was carried out holding sample membranes at the various relative pressures of permeant's vapor. The total pressure was kept at nearly atmospheric pressure by introducing nitrogen gas into an adsorption cell. The weight increase of sample

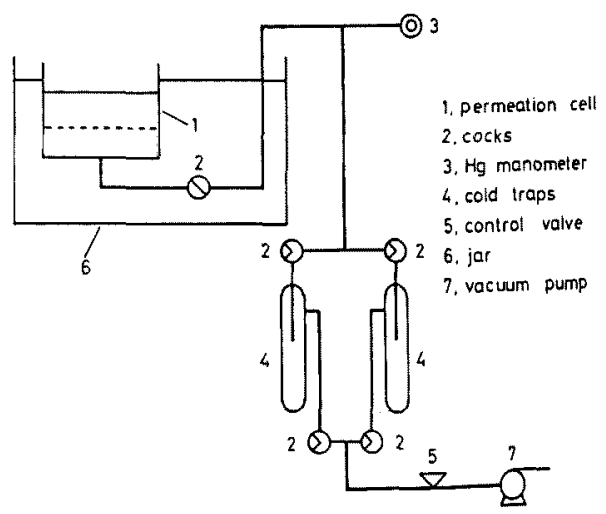

Fig. 2 A schematic diagram of pervaporation apparatus 
was determined in the adsorption cell by a differential transducer with a feed back coil. The experiments were carried out at $40^{\circ} \mathrm{C}$. The adsorption ratio $A R$ was calculated by the following equation;

$$
\operatorname{AR}(\%)=100 \times\left(W-W_{0}\right) / W_{0}
$$

where $W$ is weight of sample after adsorption and $W_{0}$ is weight of dry sample.

\section{Results and discussions}

\section{Vapor pressure profile in a cellulose acetate membrane}

The result of permeation experiment for a cellulose acetate membrane is shown in Fig. 3. When the downstream pressure is lower than the saturation pressure of each permeant at $40^{\circ} \mathrm{C}$, the mechanism of permeation can be considered clearly as pervaporation. When the downstream pressure is higher than that point, liquid permeation occurs $^{7-9)}$. In liquid permeation, the amount of permeant was too small to be detected by the apparatus used in this work. In this case, the liquid permeation was continued for 2 hours. Then the permeated liquid was forced to vaporize for 30 seconds by releasing the control valve, and was captured in the cold trap.

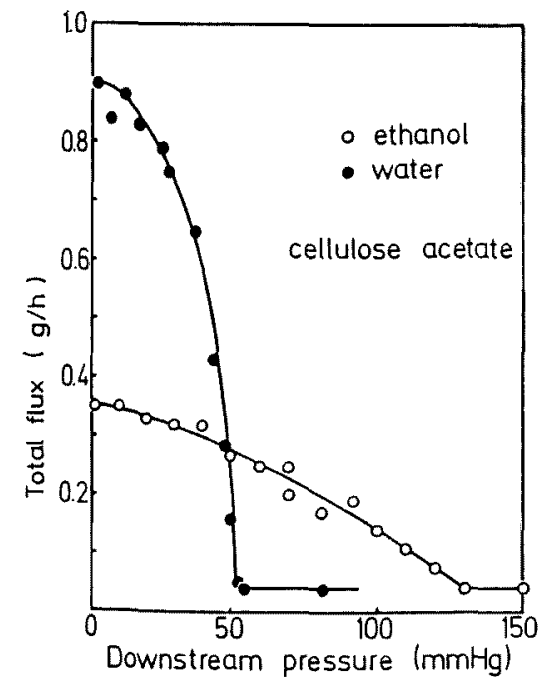

Fig. 3 The relationship between the steady-state flux and the downstream pressure for independent permeation of water and ethanol through the cellulose acetate membrane

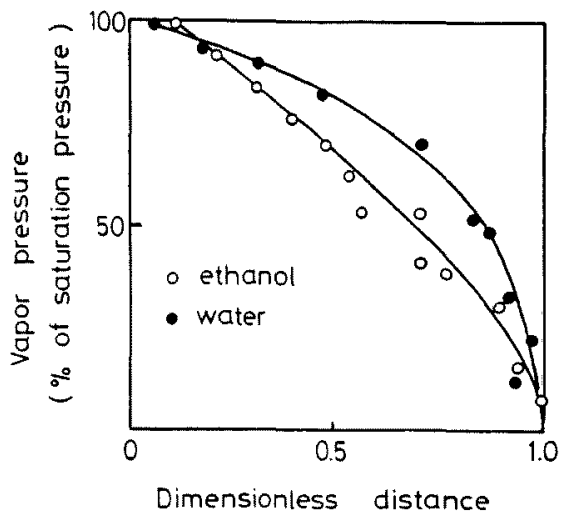

Fig. 4 Vapor pressure profile of permeant in the cellulose acetate membrane

The obtained permeation curve may cross the abscissa at the point of $760 \mathrm{mmHg}$. From such a permeation curve, the vapor pressure profile of permeant in the membrane can be determined according to the procedure mentioned in the section 2. The results are shown in Fig. 4.

\section{4-2 Concentration profile in a cellulose acetate membrane}

Fig. 5 shows the adsorption isotherms of permeants for the cellulose acetate membrane. By combining Fig. 4 and Fig. 5, the concentration profiles of permeants in the membrane can be obtained as shown in Fig. 6. The result agreed

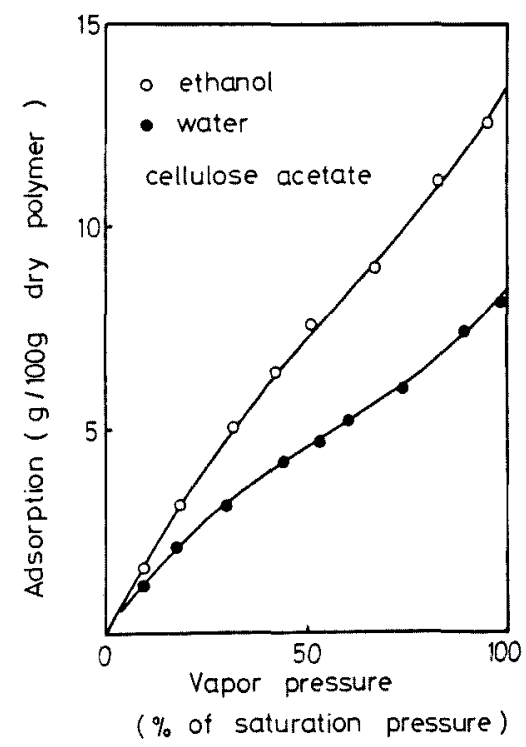

Fig. 5 Adsorption isotherm of water and ethanol for the cellulose acetate membrane 


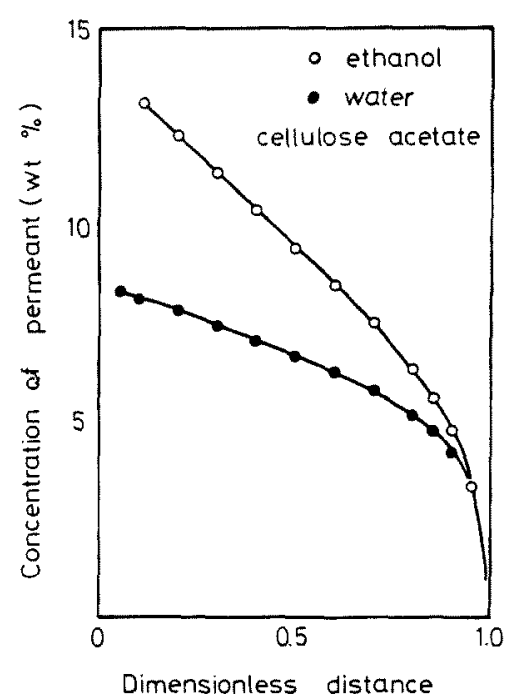

Fig. 6 Concentration profile of water and ethanol in the cellulose acetate membrane

well with other results obtained by conventional methods such as the membrane stacking experiment or the model calculation ${ }^{3-6,10)}$; the steep decrease of concentration near the downstream surface of the membrane are generally observed. Therefore reasonable results can be obtained. From the fact that the concentration gradient of ethanol is larger than that of water and the steadystate flux of water is larger than that of ethanol, the diffusion coefficient of water is much larger than that of ethanol. And one can see immediately from the rapid decrease in concentration near the downstream surface that the diffusion coefficients of both permeants decrease sharply for such systems.

On the other hand, the chemical potential of permeant in the membrane can be obtained from Fig. 4. $\mu_{0}$ stands for the chemical potential of permeant at its saturation pressure $P_{0}$. In the zone where $0<P<P_{0}$, assuming the ideality of permeant vapor, the chemical potential is expressed as follows.

$$
\mu=\mu_{0}+R T \ln \left(P / P_{0}\right)
$$

In the zone where $P_{0}<P<P_{\mathrm{a}}$, assuming that the permeant is in liquid state and its molar volume $v$ is constant at any pressure, the chemical potential is expressed as follows.

$$
\mu=\mu_{0}+v\left(P-P_{0}\right)
$$

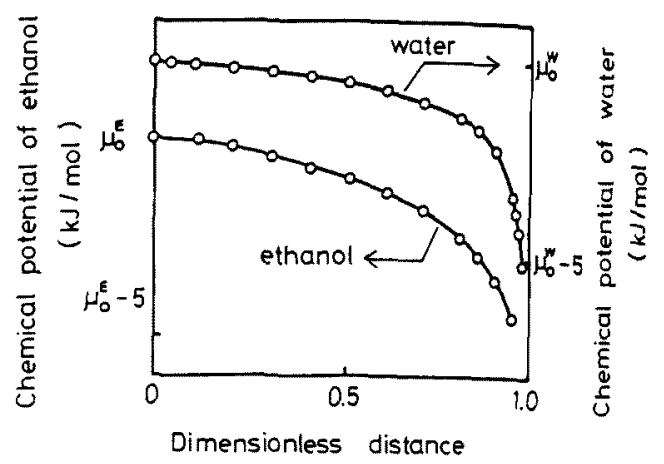

Fig. 7 Chemical potential of water and ethanol in the cellulose acetate membrane for independent pervaporation

By substituting the following values into these equations, the chemical potential is calculated as shown in Fig. 7.

$$
\begin{aligned}
& R=8.3 \mathrm{~J} / \mathrm{mol} \\
& v(\text { water })=18 \times 10^{-6} \mathrm{~m}^{3} / \mathrm{mol} \\
& P_{0}(\text { water })=55.33 \mathrm{mmHg} \\
& \quad T=40^{\circ} \mathrm{C}=313.5 \mathrm{~K} \\
& v(\text { ethanol })=58 \times 10^{-6} \mathrm{~m}^{3} / \mathrm{mol} \\
& P_{0} \text { (ethanol) }=134.28 \mathrm{mmHg}
\end{aligned}
$$

\section{4-3 Concentration profile in a silicone rubber membrane}

A series of similar experiments were carried out for a silicone rubber membrane. The result of permeation experiment is shown in Fig. 8, and the vapor pressure profile in the membrane obtained from Fig. 8 is shown in Fig. 9. The result of adsorption experiment is shown in Fig. 10.

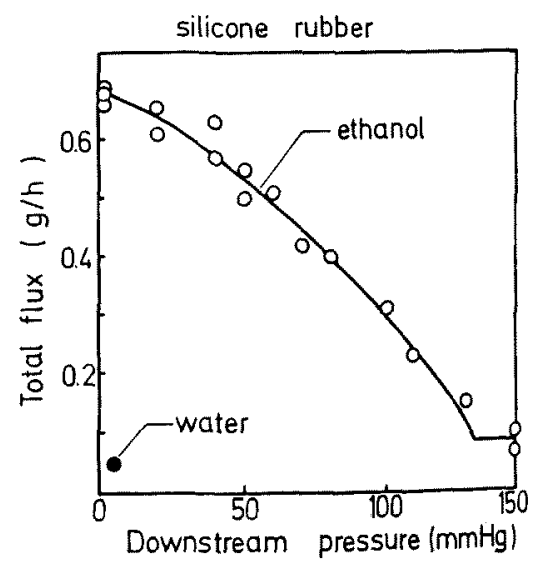

Fig. 8 The relationship between the steady-state flux and the downstream pressure for the ethanol-silicone rubber membrane system 


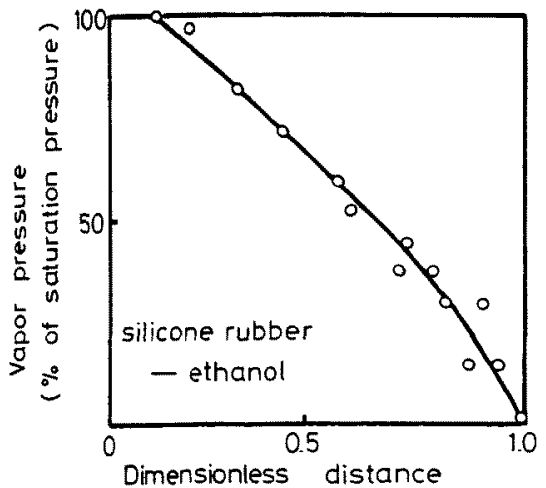

Fig. 9 Pressure profile of ethanol in the silicone rubber membrane under pervaporation

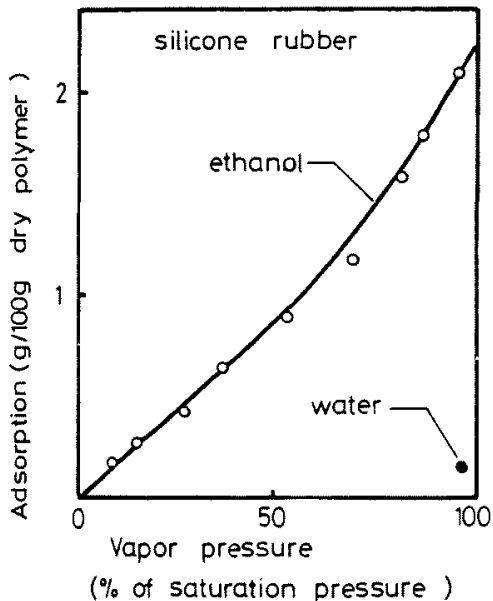

Fig. 10 Adsorption isotherm of ethanol for the silicone rubber membrane

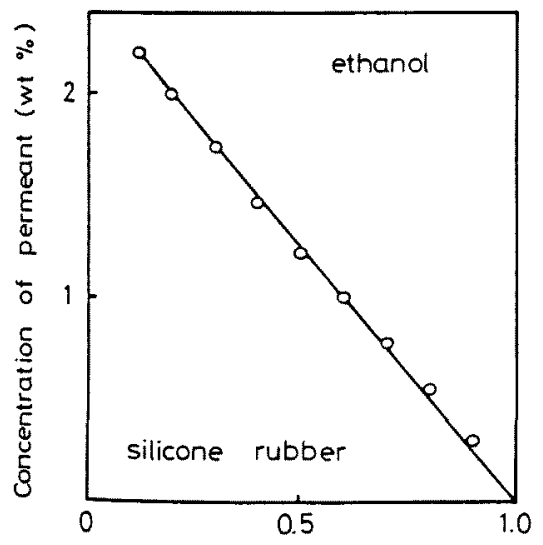

Dimensionless distance

Fig. 11 Concentration profile of ethanol in the silicone rubber membrane under pervaporation
The similar concentration profile to Fig. 6 was obtained as shown in Fig. 11. The quantities of water permeation and water adsorption were so small that the experiments were carried out using only ethanol. The concentration of ethanol in the silicone rubber membrane was low and the profile was almost linear. Concentration dependence of diffusion coefficient in silicone rubber seems to be smaller than that in cellulose acetate membrane. These conclusions agree with the previous result obtained from the adsorption rate experiment ${ }^{11)}$.

\section{4-4 Inspection on the assumption}

In order to use this method practically, two important assumptions are required.

(Assumption A): An equilibrium condition is satisfied at the interfaces.

(Assumption B): The steady-state flux is inversely proportional to the membrane thickness.

The validity of the assumption $B$ was checked for the silicone rubber membrane changing downstream pressure. Fig. 12 shows the experimental data for the membrane with thickness $115 \mu \mathrm{m}$ and $230 \mu \mathrm{m}$. The plots of solid circle mean the doubled value of the datum for the membrane with thickness $230 \mu \mathrm{m}$. As can be seen in this figure the assumption $B$ was confirmed for any downstream pressure.

The assumption $A$ means that the resistance for permeation at membrane-vapor or membraneliquid interface is so small that the diffusion process in the membrane determines the permea-

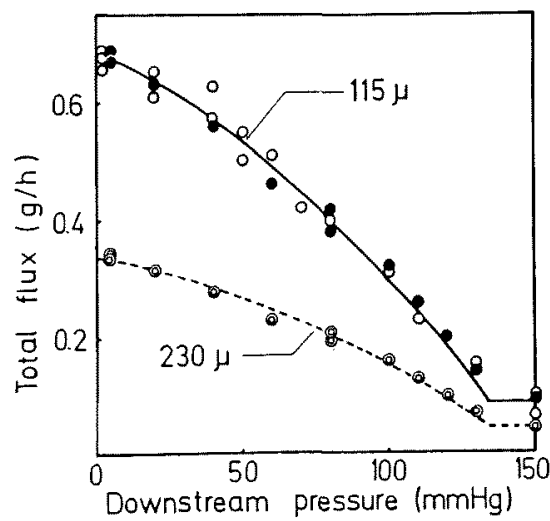

Fig. 12 The relationship berween the steady-state flux and the downstream pressure for the silicone rubber membrane of different thicknesses 
tion rate. If we consider the adsorption resistance $r_{\text {in }}$ and desorption resistance $r_{\text {out }}$ at each interface, the steady-state flux $I$ is expressed as follows;

$$
1 / J=\left(r_{\text {in }}+r_{\text {out }}+r_{\mathrm{d}} \times l\right) / \Delta \mu
$$

$\Delta \mu$ : chemical potential difference

$r_{\mathrm{d}}$ : mean value of diffusion resistance in the membrane

$l$ : membrane thickness

The experimental relationship between $1 / J$ and $l$ for the independent permeation of water and ethanol through the cellulose acetate membrane is shown in Fig. 13. As can be seen in this figure, both lines pass the original point. Therefore, the resistance of interfaces can be neglected and this fact means that the second assumption is confirmed. As the relation is linear within the thickness employed here, the first assumption is confirmed again. In the case of very thin membrane, however, the interface resistance should be considered because it becomes large as compared with diffusion resistance.

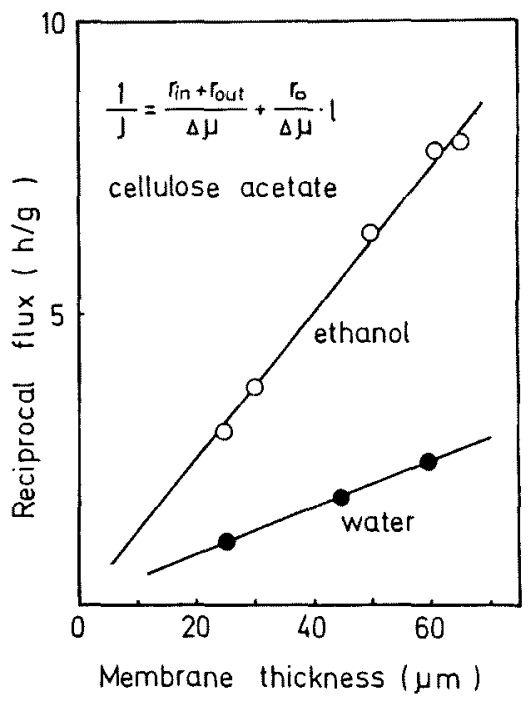

Fig. 13 The relationship between the steady-state flux and the membrane thickness for the cellulose acetate membrane under pervaporation

\section{Conclusion}

Using the method proposed in this study, the concentration profiles of single permeant in membranes under pervaporation can be obtained precisely. This method will be especially useful for the permeants which have high volatility, or high diffusivity in the membrane. The expermental results showed good agreement in shape with previous works. In addition, the assumptions required for this method were confirmed experimentally. This method was applicable for the permeant-membrane systems treated here.

\section{Literature cited}

1) J. Néel: Proceedings of First International Conference on Pervaporation Process in the Chemical Industry, 10 (1986)

2) O. Kedem: Proceedings of First International Conference on Pervaporation Process in the Chemical Industry, 111 (1986)

3) S. N. Kim and K. Kammermeyer: Sep. Sci. 5, $679(1970)$

4) P. Aptel, J. Cuny, J. Jozefonvicz, G. Morel and J. Néel: J. Appl. Polym. Sci., 18, 365 (1974)

5) M. H. V. Mulder, A.C. M. Franken and C. A. Smolders: J. Memb. Sci., 23, 41 (1985)

6) R. B. Long: I\&EC fundamentals, 4, 445 (1965)

7) F. W. Greenlaw, W. D. Prince, R. A. Shelden and E. V. Thompson: J. Memb. Sci., 2, 141 (1977)

8) A. Duggal and E. V. Thompson: J. Memb. Sci., 27, 13 (1986)

9) D. R. Paul and O. M. Ebra-lima: J. Appl. Polym. Sci., 14, 2201 (1970)

10) J. P. Brun, C. Larchet, R. Melet and G. Bulvestre: J. Memb. Sci., 23, 257 (1985)

11) S. Nishioka, H. Kita, K. Okamoto and S. Asagawa: Proceedings of 51st Annual Meet ing of the Society of Chemical Engineers, Japan, K121 (1986) 
(47)

$$
\begin{aligned}
& \text { パーベーパレーションにおける膜中での透過物質の濃度分布 } \\
& \text { 一測定方法の提案— } \\
& \text { 織維高分子材料研究所岩坪 隆, 山中忠衛, 山本正秀, } \\
& \text { 溝口健作，須田昌男 }
\end{aligned}
$$

二次側压力を変化させてパーベーパレーションを行な った結果と膜に対する透過物質の吸着等温線とから膜中 での透過物質の濃度分布を決定することを試みた。対象 とした系はセルロースアセテート膜一水，セルロースア 奵ート膜一エタノールおよびシリコーンゴム膜一エ夕 ノールである。得られた濃度分布は別の方法による既往 の叝告と形状的に一致した。またこの方法で用いられた
幾つかの仮定を実験的に検討しその妥当性を確認した。 よって上記の系伅ついてはての方法を用いることが可能 であると結論つけられた。

ての方法によれば詳細な濃度分布を求めるととができ， かつ透過物質が揮発しやすい場合やその应散性が高い場 合に特に有効であると考えられる。 